\title{
Oral L-citrulline supplementation enhances cycling time trial performance in healthy well-trained males
}

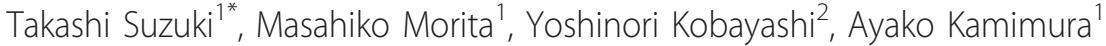 \\ From The Twelfth International Society of Sports Nutrition (ISSN) Conference and Expo \\ Austin, TX, USA. 11-13 June 2015
}

\section{Background}

L-citrulline is an amino acid that is an endogenous precursor of L-arginine and contributes to generating nitric oxide (NO). L-citrulline is known for increasing plasma $\mathrm{L}$-arginine and $\mathrm{NO}$ more effectively than equivalent doses of L-arginine. NO plays an important role in sport performance but it is presently unknown whether L-citrulline enhances sport performance during rowing ergometer competition in humans. The aim of this study is to investigate the effect of oral supplementation of L-citrulline on cycling time trial performance.

\section{Methods}

A randomized double-blind crossover study design was used. Twenty two well-trained males, aged between 20 and 39 , consumed $2.4 \mathrm{~g} /$ day of L-citrulline or placebo for 7 days and they took $2.4 \mathrm{~g}$ of L-citrulline or placebo 1 hour before $4 \mathrm{~km}$ cycling time trial on day 8 . Completion time of $4 \mathrm{~km}$ cycling, power output / $\mathrm{VO}_{2}$ ratio (PO / $\mathrm{VO}_{2}$ ), plasma NOx, amino acids, Visual Analog Scale (VAS) were evaluated.

\section{Results}

L-citrulline supplementation significantly improved cycling time trial performance by $1.5 \%(\mathrm{p}<0.05)$ and increased $\mathrm{PO} / \mathrm{VO}_{2}$ during performance $(\mathrm{p}<0.1)$. Moreover there was a correlation between plasma NOx and $\mathrm{PO} / \mathrm{VO}_{2}(\mathrm{r}=0.47, \mathrm{p}<0.01)$ in L-citrulline group. L-citrulline significantly increased plasma L-citrulline and L-arginine, and improved the subjective feeling of muscular fatigue and concentration $(\mathrm{p}<0.05)$.
'Healthcare Products, Development Center, KYOWA HAKKO BIO Co., Ltd, Tokyo, Japan

Full list of author information is available at the end of the article

\section{Conclusion}

Oral L-citrulline supplementation enhances cycling time trial performance by improving $\mathrm{PO} / \mathrm{VO}_{2}$ through upregulation of plasma $\mathrm{NO}$ availability.

\section{Authors' details}

'Healthcare Products, Development Center, KYOWA HAKKO BIO Co., Ltd, Tokyo, Japan. ${ }^{2}$ Laboratory of Pharmacognosy, School of Pharmaceutical Sciences, Kitasato University, Tokyo, Japan.

Published: 21 September 2015

doi:10.1186/1550-2783-12-S1-P52

Cite this article as: Suzuki et al:: Oral L-citrulline supplementation enhances cycling time trial performance in healthy well-trained males. Journal of the International Society of Sports Nutrition 2015 12(Suppl 1):P52.

\section{Submit your next manuscript to BioMed Central and take full advantage of: \\ - Convenient online submission \\ - Thorough peer review \\ - No space constraints or color figure charges \\ - Immediate publication on acceptance \\ - Inclusion in PubMed, CAS, Scopus and Google Scholar \\ - Research which is freely available for redistribution \\ Submit your manuscript at www.biomedcentral.com/submit}

